\title{
PIEZOCONDUCTIVITY OF CHIRAL CARBON NANOTUBES IN THE FRAMEWORK OF THE TIGHT-BINDING METHOD
}

\author{
Olga Sergeevna Lebedeva
}

Candidate of Physical and Mathematical Sciences, Assistant, Department of Theoretical Physics and Wave Phenomena, Volgograd State University lebedeva_os@volsu.ru, tf@volsu.ru Prosp. Universitetsky, 100, 400062 Volgograd, Russian Federation

\section{Nikolay Gennadyevich Lebedev}

Doctor of Physical and Mathematical Sciences, Professor, Department of Theoretical Physics and Wave Phenomena, Volgograd State University nikolay.lebedev@volsu.ru,tf@volsu.ru Prosp. Universitetsky, 100, 400062 Volgograd, Russian Federation

\section{Irina Aleksandrovna Lyapkosova}

Candidate of Agricultural Sciences,

Associate Professor, Department of Mechanics,

Volgograd State Agrarian University

lyapkosova irina@mail.ru

Prosp. Universitetsky, 26, 400002 Volgograd, Russian Federation

\begin{abstract}
The results of a theoretical study of the piezoresistive properties of chiral carbon nanotubes with different types of conductivity are presented in this paper. An analytical expression for an electron spectrum of the chiral deformed carbon nanotubes has been obtained using the tight-binding method. External mechanical loads lead to band gap changes of the studied nanoparticles, which has an indirect influence on its conductivity. This change of conductivity due to a deformation is called piezoresistance effect, which is characterized by piezoresistive constants. In the framework of the Hubbard model and the Green function method, an analytic calculation of such constants, the longitudinal component of the elastoconductivity tensor, has been carried out. Its dependence on nanotubes' diameter, the magnitude of relative deformation of longitudinal compression and stretching are investigated.
\end{abstract}


Key words: elasto-conductivity tensor, piezoresistance effect, compression and expansion deformation, band gap.

\section{Introduction}

One of the priority trends of modern microelectronics is the development of technologies for designing devices, whose operation is based on the piezoresistance effect, such as resonators, pressure and strain sensors, actuators, energy harvestors, sound generators, etc. $[4 ; 13 ; 15]$. The discovery of new promising nanomaterials with unique piezoresistance properties involves its comprehensive investigation to achieve the aim. Electronic characteristics of carbon nanoparticles (carbon nanotubes, graphene, graphene ribbons) are sensitive to external mechanical stress $[3 ; 4 ; 13 ; 15]$. Devices of MEMS (microelectromechanical systems) technology operation [2] whose main structural element are carbon nanotubes and graphene in the future promise to be miniature, lightweight and ultra-sensitive nanoelectronics of next generation $[2 ; 4]$.

A change of energy gap and conductivity of deformed semiconductor carbon nanoparticles leads to the piezoresistance effect, which is quantitatively characterized by piezoresistance constants, such as the gauge factor and tensors of elastoresistance, piezoresistance and elastoconductivity [1]. Ahigh sensitivity of the conductance properties of carbon nanotubes (CNTs) to mechanical deformations offers new prospects for using nanotubes as the main structural element of piezoresistance and pressure sensors [2]. A quantitative calibration of such devices is based on the use of piezoresistance constants, an analytical calculation of which is carried out in the paper.

The mathematical model of electronic structure of the zig-zag and arm-chair carbon nanotubes deformed by a volume expansion (compression) and an axial stretching (compression) as ideal, and with acceptor and donor point defects of replacement is constructed in works [7-10]. The model also takes into account transverse deformation in the linear approximation on a deformation potential on the basis of the tightbinding method within the framework of Hubbard's model [5]. Theoretical calculation of a longitudinal component of the elastoconductance tensor [10] of carbon nanotubes as functions of the relative deformation of volume expansion (compression) and an axial stretching (compression) is carried out.

A complete theoretical review of piezoresistance properties of carbon nanoparticles is impossible without studying piezoconductivity of the chiral CNTs [17]. Modelling of its electronic structure is carried out by means of introduction of the straining potential considering variation of interatomic bond lengths and valence angles. The piezoresistance research of the chiral CNTs by calculating its main characteristic - an elastoconductance tensor, and by studying its dependence on a value and a type of deformation.

\section{Model of the electronic structure of deformed chiral carbon nanotubes}

A two-dimensional hexagonal graphene layer is chosen as the geometric model of chiral CNTs (Fig. 1). It is characterized by the chiral vector $\mathbf{C}_{\mathbf{h}}=n \boldsymbol{a}_{1}+m \boldsymbol{a}_{2}$, where $n$ and $m$ are integers, $\boldsymbol{a}_{1}$ and $\boldsymbol{a}_{2}$ are the main translation vectors. The axis OY of the coordinate system is directed along the CNT axis, the ribbon width is measured along the axis OX. The angle $\theta=\angle\left(\mathbf{C}_{\mathbf{h}}, \mathbf{a}_{1}\right)$ between $\mathbf{C}_{\mathbf{h}}$ and $\boldsymbol{a}_{\mathbf{l}}$ vectors lies in the range $0 \div 30^{\circ}$ and is called the chiral one [3]. The CNT electron energy spectrum are described using two-dimensional dispersion relation, which has the following form in the framework of the Hucckel approximation and tight-binding method [17]:

$$
\begin{aligned}
& \varepsilon(\boldsymbol{k})= \pm \gamma_{0}\left\{3+2 \cos \left(\boldsymbol{k} \boldsymbol{a}_{1}\right)+2 \cos \left(\boldsymbol{k} \boldsymbol{a}_{2}\right)+2 \cos \left(\boldsymbol{k}\left(\boldsymbol{a}_{1}-\boldsymbol{a}_{2}\right)\right)\right\}^{1 / 2}= \\
& = \pm \gamma_{0}\left\{1+4 \cos \left(\frac{\boldsymbol{k}\left(\boldsymbol{a}_{1}+\boldsymbol{a}_{2}\right)}{2}\right) \cos \left(\frac{\boldsymbol{k}\left(\boldsymbol{a}_{1}-\boldsymbol{a}_{2}\right)}{2}\right)+4 \cos ^{2}\left(\frac{\boldsymbol{k}\left(\boldsymbol{a}_{1}-\boldsymbol{a}_{2}\right)}{2}\right)\right\}^{1 / 2}
\end{aligned}
$$

where $\gamma_{0}$ is the jumping integral, $\mathbf{k}$ is a wave vector, one of whose components is quantized along the tube perimeter. Fermi level is equal to $0 \mathrm{eV}$. Different signs in the dispersion relation refer to the conduction band and the valence band correspondently. 


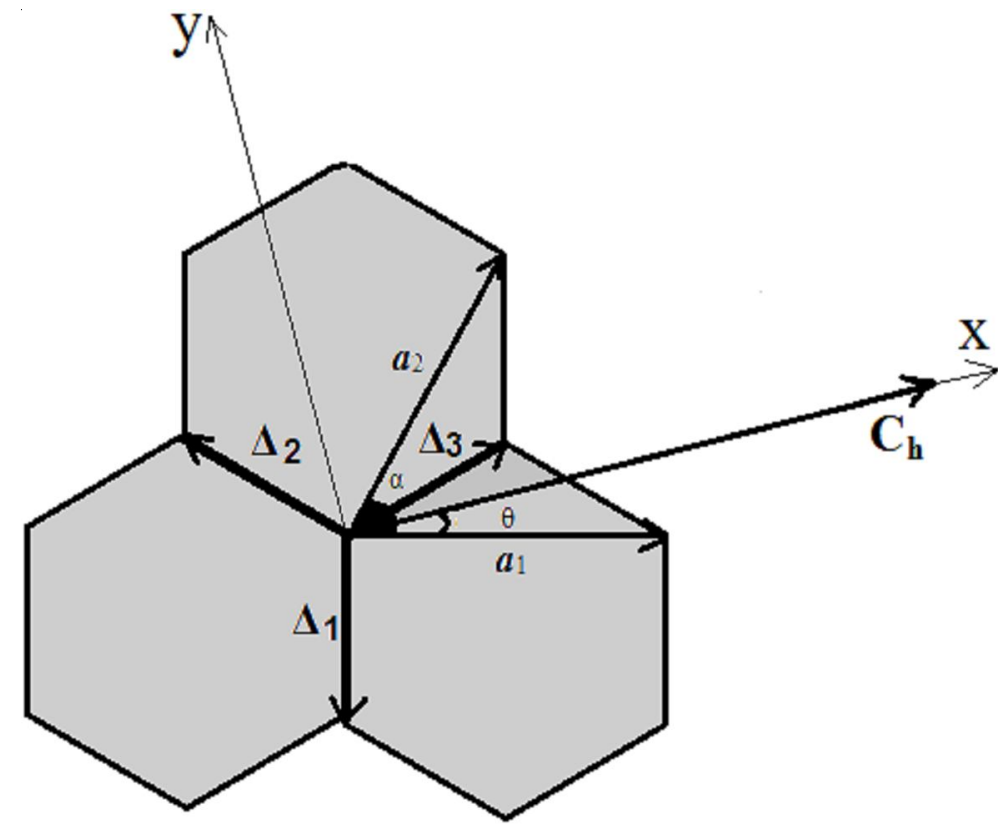

Fig. 1. Fragment of the chiral CNT structure with the selected coordinate system:

$\Delta_{1}, \Delta_{2}, \Delta_{3}$ are interatomic vectors between vicinity neighbours, $\boldsymbol{a}_{1}, \boldsymbol{a}_{2}$ are translation vectors, $\alpha$ is the angle between the translation vectors, $\theta$ is the chiral angle, $\mathbf{C}_{\mathbf{h}}$ is the chiral vector

The condition for quantizing of the wave vector $\mathbf{k}$ along the direction of the chiral vector $\mathbf{C}_{\mathbf{h}}$ is as follows [17]:

$$
\mathbf{k} \cdot \mathbf{C}_{\mathbf{h}}=2 \pi q, \text { where } q=1,2, \ldots
$$

The components of the wave vector $k_{x}$ and $k_{y}$ are co-directed with the chiral vector $\mathbf{C}_{\mathbf{h}}$ and the CNT axis respectively, i.e. $\mathbf{k}_{\mathbf{x}} \uparrow \uparrow \mathbf{C}_{\mathbf{h}}$ and $\mathbf{k}_{\mathbf{y}} \perp \mathbf{C}_{\mathbf{h}}$. The module of the chiral vector of deformed CNTs can be represented on the basis of its definition [1]:

$$
\left|\boldsymbol{C}_{\boldsymbol{h} 0}\right|=\sqrt{n \cdot \boldsymbol{a}_{1}^{2}+m \cdot \boldsymbol{a}_{2}^{2}+2 n m \boldsymbol{a}_{1} \boldsymbol{a}_{2}}=a \sqrt{n^{2}+m^{2}+n m} .
$$

With the help of (3) and conditions (2), an explicit expression for quantizing the transverse component of the wave vector can be obtained:

$$
k_{x} a=\frac{2 \pi q}{\sqrt{n^{2}+m^{2}+n m}}, \quad q=1,2, \ldots,\left[\sqrt{n^{2}+m^{2}+n m}\right] .
$$

The arguments of trigonometric functions in the dispersion (1) can be written in the following form:

$$
\begin{aligned}
& \frac{\boldsymbol{k}\left(\boldsymbol{a}_{1}+\boldsymbol{a}_{2}\right)}{2}=\left(\frac{1}{\sqrt{n^{2}+m^{2}+n m}} \cdot\left(\frac{3 \pi q(n+m)}{2 \sqrt{n^{2}+m^{2}+n m}}+\frac{\sqrt{3} k_{y} a(n-m)}{4}\right)\right), \\
& \frac{\boldsymbol{k}\left(\boldsymbol{a}_{1}-\boldsymbol{a}_{2}\right)}{2}=\left(\frac{1}{\sqrt{n^{2}+m^{2}+n m}} \cdot\left(\frac{\pi q(n-m)}{2 \sqrt{n^{2}+m^{2}+n m}}-\frac{\sqrt{3} k_{y} a(n+m)}{4}\right)\right) .
\end{aligned}
$$

As a result, expression (1) and relation (5) completely determine the electron energy spectrum of non-deformed chiral CNTs.

The energy spectrum of deformed chiral CNTs is based on the expressions (5) modification. The change of the CNT unit cell under the effect of the stretching strain is shown in Figure 2. The illustration 
shows the deformation leads not only to the lengths of the interatomic bonds $\Delta_{i}=R_{0}(1+\delta)$ change by the value of their relative elongation $\delta=\Delta R / R_{0}$, but also to the modification of the angle between translation vectors $\alpha=\alpha_{0}+\Delta \alpha\left(\alpha_{0}=\pi / 3\right.$ is the angle between the translation vectors in the non-deformed lattice), and, therefore, the translation vectors $\boldsymbol{a}_{1}$ and $\boldsymbol{a}_{2}$ projections on the axis OX and OY of the chosen coordinate system.

The expression for the band structure of the deformed chiral CNT can be obtained on the basis of geometric transformations (Fig. 2). In the result the electron spectrum of these CNTs is as follows:

$$
\varepsilon(\mathbf{k})= \pm \gamma\left(1+4 \cos \left[\pi n A_{1}+B_{1}\right] \cos \left[\pi n A_{2}-B_{2}\right]+4 \cos ^{2}\left[\pi n A_{2}-B_{2}\right]\right)^{1 / 2},
$$

where the following notation is introduced:

$$
\begin{gathered}
A_{1}=\frac{F \cos \alpha+G \sin \alpha}{A \cos \alpha+B \sin \alpha}, \quad B_{1}=k_{y} R_{0}(1+\delta)(-G \cos \alpha+F \sin \alpha), \\
A_{2}=\frac{-E \cos \alpha}{A \cos \alpha+B \sin \alpha}, \quad B_{2}=k_{y} R_{0}(1+\delta) E \sin \alpha, \\
E=n \sin \theta \cos \left(2 \alpha_{0}\right)+m \cos \theta \cos \left(\frac{\alpha_{0}}{2}\right), B=\sin \theta\left[n \sin \left(2 \alpha_{0}\right)+m \cos \left(\frac{\alpha_{0}}{2}\right)\right],
\end{gathered}
$$

Fig. 2. Positions of interatomic vectors $\Delta_{1}, \Delta_{2}, \Delta_{3}$ after deformation of tensile (compression) with its rotation at the angle $\Delta \alpha$

The change of the transverse dimensions (diameter) of CNTs as a result of deformation is taken into account by modifying the chiral vector $\mathbf{C}_{h}$ modulus, which can be calculated by the following formula from the definition of Poisson's ratio and directly proportional to the geometric parameters of nanotubes: 


$$
\mathrm{C}_{h}=(1-v \cdot \delta) \mathrm{C}_{h 0},
$$

where $v$ is the Poisson ratio. Its value for CNTs is in the range of $v=0.19 \div 0.27$.

The expression (9) and the selected geometric model of the deformed chiral CNTs allow to determine the angle $\alpha$ between the translation vectors in deformed hexagonal lattice included in the description for the coefficients of (7) spectrum of CNTs (6):

$$
\sin \alpha=\frac{B C+A \sqrt{B^{2}-C^{2}+A^{2}}}{A^{2}+B^{2}},
$$

where

$$
C=\frac{1-v \delta}{1+\delta}\left[\sin \theta\left(n \cos \alpha_{0}+m \cos ^{2}\left(\frac{\alpha_{0}}{2}\right)\right)+\frac{m}{2} \cos \theta \sin \alpha_{0}\right],
$$

and the coefficients $A$ and $B$ are expressed by formula (8).

The following values of the relative tensile strain (compression) $\delta= \pm 0.035, \pm 0.069, \pm 0.104,0.25$, appropriate to the interatomic bond lengths $R=1.49,1.54,1.59,1.8 \AA$ in the case of stretching and $R=1.39$, $1.34,1.29 \AA$ in the case of compression, are used in the work for the theoretical calculations. The electronic spectrum of deformed $(\delta=0.035)$ chiral CNTs, taking into account the transverse deformations, is shown in Figure 3 for a series of CNTs $(3,1),(7,3)$ and $(7,4)$ of different diameters and conductivity type: semiconductor with wide band gap, semiconductor with a thin band gap and a conductor respectively.

The reduction of the band gap of semiconducting CNTs under tension and increases under compression is important consequence of the influence of deformations on the electronic spectrum of chiral CNTS, in our opinion. This effect is fundamentally different from the case of energy gap change of deformed achiral semiconducting (zig-zag) CNTs, circumstantially analyzed in [8], and is associated with the fact that two-dimensional extended Brillion zone (BZ), which is a hexagon in the space of wave vectors, is also modified (compressed and stretched) as a result of tensile (compression) deformation [17]. And its change occurs along the lines of the continuous $k_{y}$-component of the wave vector, whose position in the Brillion zone is determined by quantizing the $k_{x}$-component as noted above. Taking into account the transverse deformation of CNTs leads to the stretching (compression) of the BZ in the direction of the $x$-axis respectively. As a result of this asymmetric deformation, the lines of the continuous wave vector approach to the singular $K$-points (the Dirac points [12]) of the Brillion zone, in which the $\mathrm{VZ}$ and $\mathrm{CZ}$ of graphene intersect or move away from them as a function of the deformation $\delta$. It leads to a decrease (increase) of the band gap (Fig. 3b) respectively.

In the case of conducting chiral CNTs, for example $(7,4)$, longitudinal stretching (compression) also changes its band structure as described above and fundamentally differs them from arm-chair and conductive zig-zag nanotubes. Indeed, the deformation of the Brillion zone leads, in opposite, to the removal of the lines of the continuous component of the wave vector from the vertex $K$-points, as a result of which a band gap appears in the electronic spectrum (Fig. 3c), which changes the electronic properties of the tube. This effect is observed only in metallic chiral CNTs and is absent in achiral nanotubes, in which the energy gap in the spectrum does not appear due to expansion deformation (compression).

In this case, even a small deformation of the BZ along the direction of the continuous component of the wave vector can lead to a shift of the quantization lines of the transverse component, to its forthcoming (or move away) to the Dirac points and the appearance (or disappearance) of the energy gap in the spectrum. Therefore, for chiral tubes, transitions of the Mott-type "conductor-semiconductor" and "semiconductor-conductor" are possible due to axial strains of expansion. 

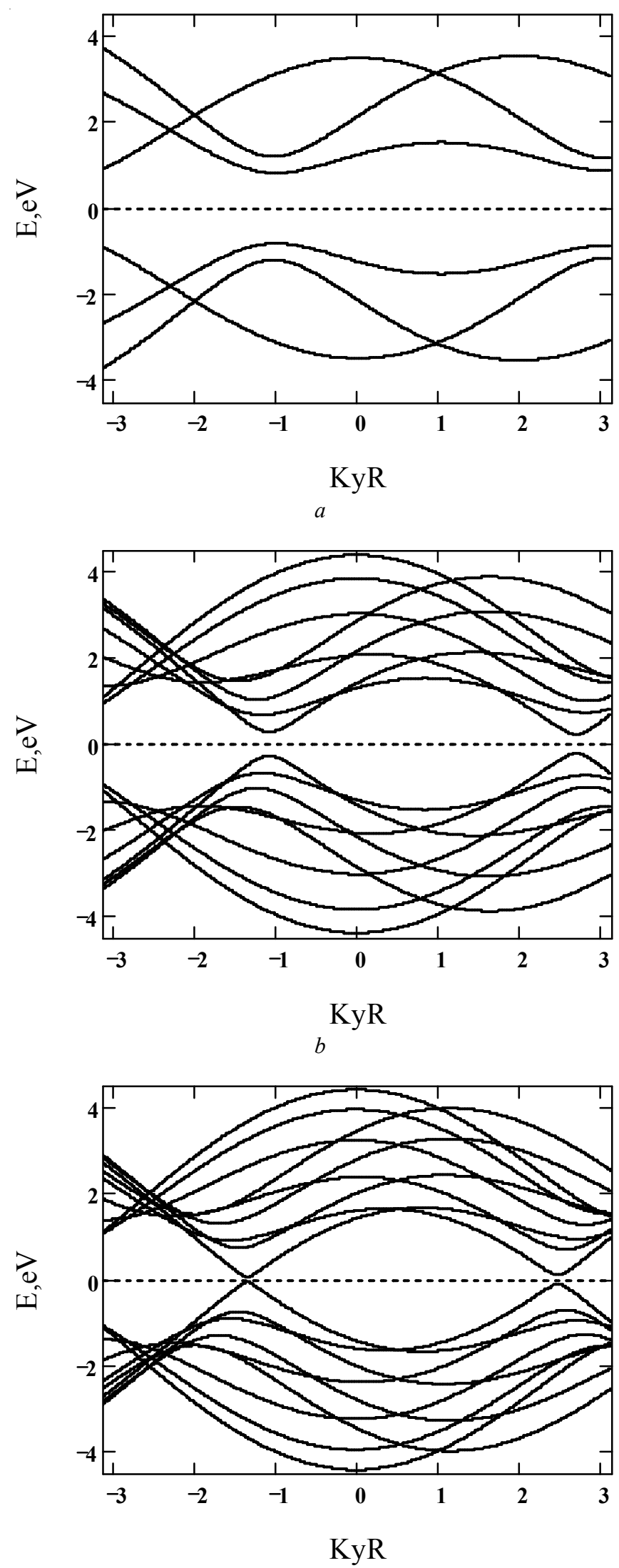

Fig. 3. Band structure of the khiral CNTS:

$a-(3,1) ; b-(7,3) ; c-(7,4)$ deformed by the $3.5 \%$ stretching 


\section{Elastoconductivity of chiral CNTs}

The calculation of piezoresistance constants (a longitudinal component of the elastoconductance tensor) of chiral CNTs is carried out by the method described in detail in the works [7;9;10]. Proceeding from the definition of the elastoconductance tensor [1], its longitudinal component for one-dimensional structures can be expressed by the following formula:

$$
M=\frac{\Delta \sigma}{\sigma_{0}} \frac{1}{\delta}
$$

where $M=m_{z z z z}$ is the longitudinal component of the 4 th rank elastoconductance tensor, $\Delta \sigma=\sigma-\sigma_{0}$ is the change of longitudinal components of the conductivity tensor due to the deformation of a crystallite, $\sigma$ and $\sigma_{0}$ are longitudinal $\sigma_{z z}$ components of the $2 n d$ rank conductance tensor of the deformed and nondeformed crystal respectively.

The longitudinal component of the tensor of the specific non-phonon conductance of CNTs is calculated within the framework of the Kubo-Greenwood theory [6] with the Green's function formalism [11] application and the use of the tight-binding Hamiltonian model. The final expression for the longitudinal conductivity of CNTs used in the calculations of the constant $M$ has the following form [9]:

$$
\sigma=2 \frac{i \pi e^{2}}{k_{B} T V} \sum_{\mathbf{k}, \alpha} \sum_{\mathbf{q}, \beta} v(\mathbf{k}) v(\mathbf{q})<n_{\mathbf{k} \alpha}>\left[<n_{\mathbf{q} \beta}>+\delta_{\mathbf{k q}} \delta_{\beta \alpha}\left(1-<n_{\mathbf{k} \alpha}>\right)\right],
$$

where $V$ is nanotube 2D-volume, $k_{B}$ is Boltzmann constant, $T$ is an absolute temperature, $e$ is elementary charge, $k, q$ are two-component wave vectors within the $\mathrm{ZB}, \alpha, \beta$ are spin indexes, $v$ is the longitudinal component of the velocity vector $\mathbf{v}(\mathbf{k})=\partial \varepsilon(\mathbf{k}) / \partial(\mathrm{h} \mathbf{k})$ of the electron in the $\mathrm{ZB},<n_{\mathbf{k} \alpha}>$ is the average number of particles in a quantum state with wave vector $\mathbf{k}$ and spin $\alpha$, expressed by the distribution function Fermi-Dirac.

Dependences of the elastoconductance tensor component $M$ on the relative deformation $\delta(=-0.104$, $-0.069,-0.035,0.035,0.069,0.104,0.25)$ for chiral CNTs of different diameter and type of conductivity $(3, m)$, $(6, m),(7, m)$, where $m=1, \ldots, n-1$, is presented in Fig. 4. Numerical results are obtained at a temperature $T=300 \mathrm{~K}$. Calculated points are connected by solid lines to visualize the representation of the constant $M$. It should be understood that the point $\delta=0$ is not defined.

As can be seen from Fig. 4, the longitudinal component $M$ of chiral CNT is positive and its behaviour is completely correlated with changes of the band structure described above. The general feature for most of the considered CNTs is monotonic decreasing of constant $M$ with increasing relative deformations of tensile (compression) $\delta$ that is significantly different from achiral nanotubes. This behaviour is due to a qualitative and quantitative change of the band structure described above, the consequence of which is the change of the state density with increasing magnitude of deformation and the variation of the band gap due to the deformation of the Brillion zone. Thermal fluctuations lead to the filling of the conduction band of CNTs by electrons according to the Fermi-Dirac distribution function. The electron spectrum modification results in the change of the conductivity taking into account all possible filled electronic states, and, consequently, to the reduction of the component $M$ with increasing and decreasing $\delta$. The decrease of the $M$ component in both stretching and compression is due to the fact that as a result of deformation of the crystallite, the lines of allowed values of the $k_{x}$-component approach one of the $K$ points of the ZB and are removed from the others. As a result, the band gap decreases for any type of deformation.

An exception is the tube $(3,2)$ case, as well as some other tubes of small diameter, for example $(4,2)$, etc. which behave as the conductive arm-chair CNT [8]. It is connected with the fact that its chiral angle is close to $30^{\circ}$ as well as "arm-chair" nanotubes therefore at the expansion (compression) deformation the line of the allowed values $k_{x}$-components of a wave vector are forthcoming (or moving away) ZB $K$-points. 


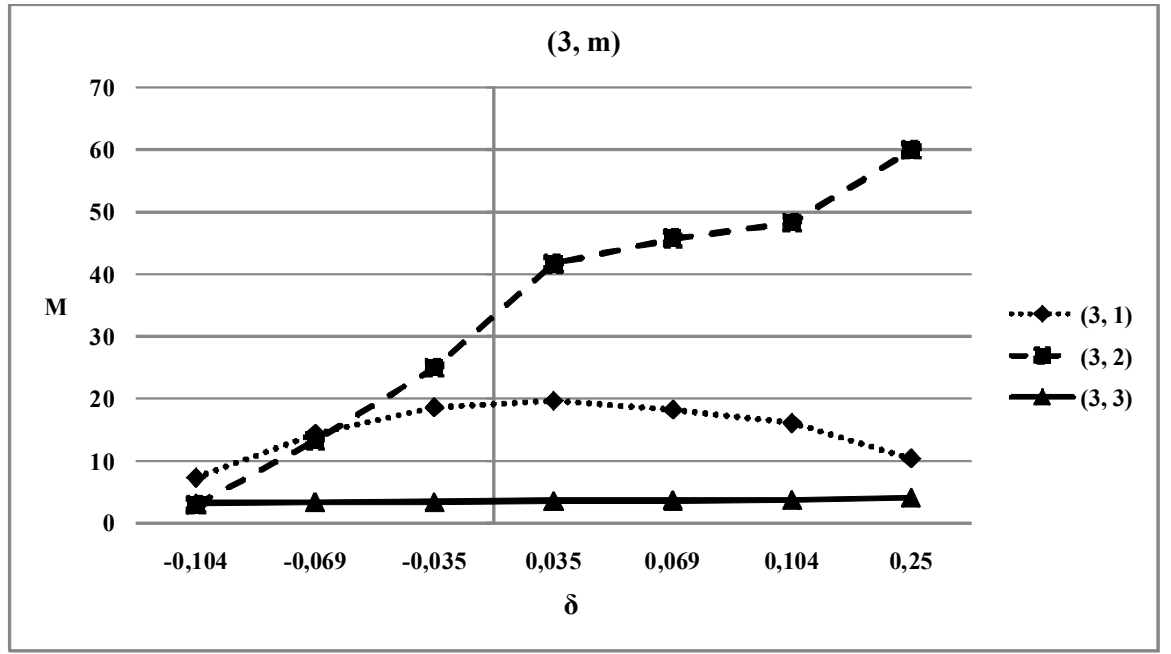

$a$

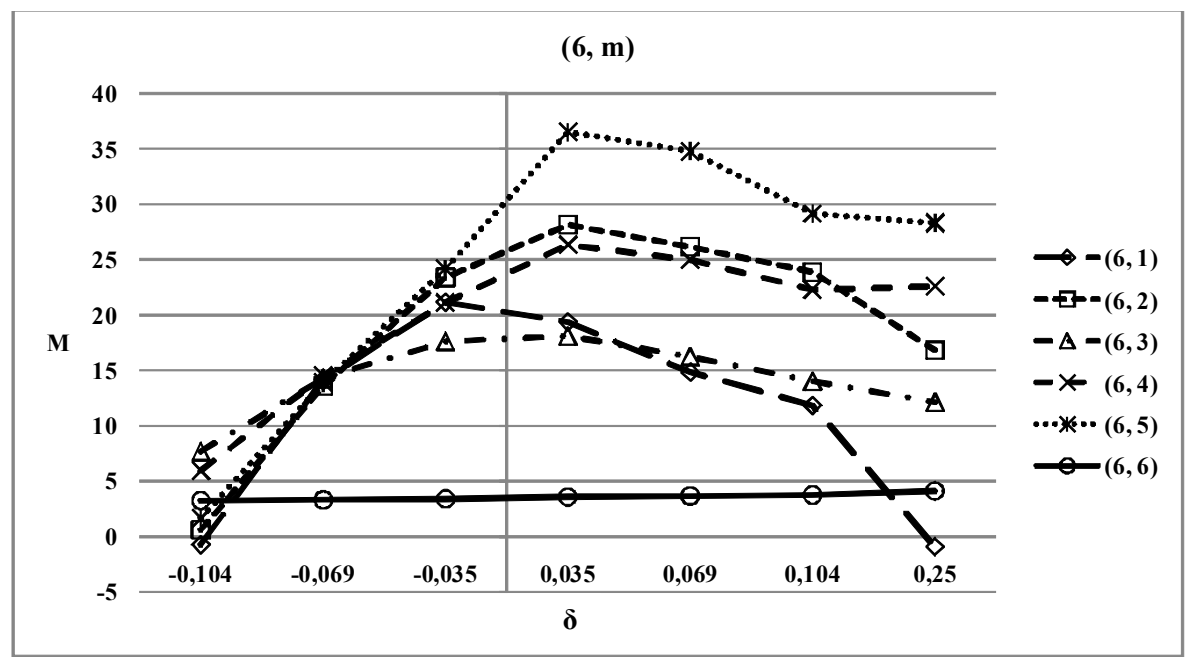

$b$

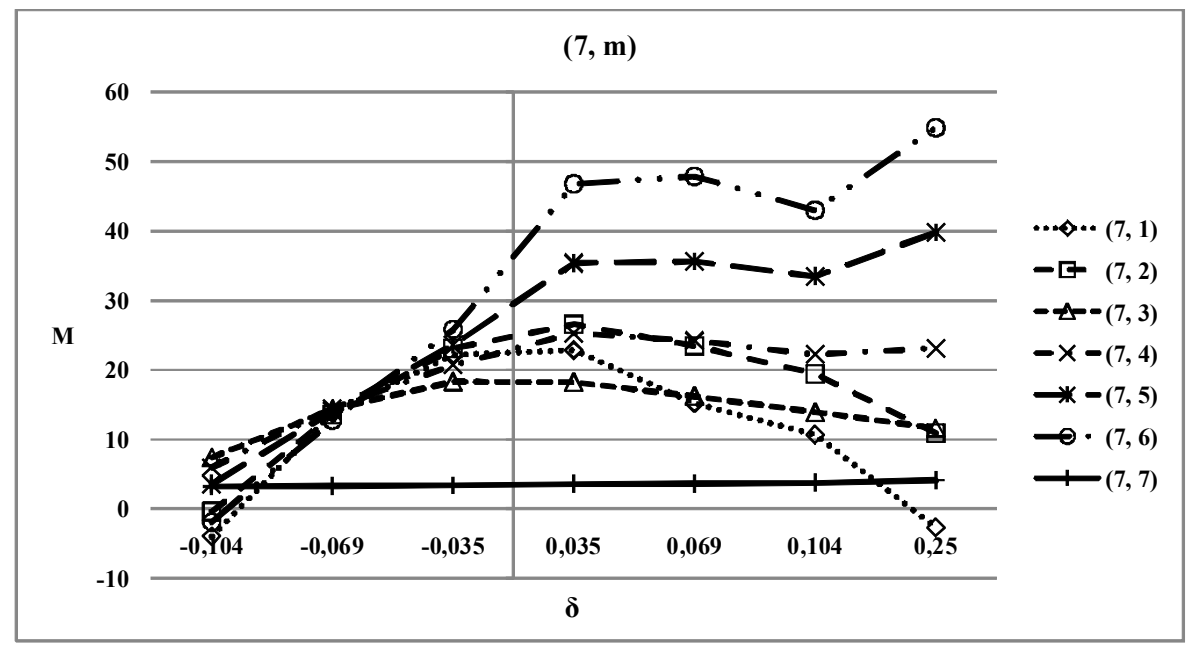

$c$

Fig. 4. The longitudinal component $M$ of the elastoconductance tensor of chiral CNTs as a function of the relative deformation $\delta$ of axial tension and compression: $a-(3, m) ; b-(6, m) ; c-(7, m)$. The point $\delta=0$ is not defined on all curves 
Besides, for tubes of large diameter, such as $(7,5)$ and $(7,6)$ at axial tension it is observed oscillatory dependence of $M$ on $\delta$, also corresponding to the features of the band structure of deformed chiral CNTs, described in the previous paragraph.

As can be seen from Fig. 4, the exception to the general behaviour of the component $M$ is the maximum permissible deformation $\delta_{\text {end }}=0.25$, which leads to an increase of the piezoresistance constant under strong tension (compression). The limit value of deformation corresponds to the experimental data and is the elastic deformation under compression (expansion) of less than $25 \%$, as shown in [16].

The dependence of the tensor component $M$ for a series of chiral CNTs, for example $(6, \mathrm{~m})$ (Fig. 4b) and (7, m) (Fig. 4c) on its diameter, i.e. in this case, on the index $\mathrm{m}$, for a given $\delta$ value is nonmonotonic (oscillating), which is directly related to the dependence of the electronic spectrum of such tubes on the chiral angle (chiral effect) [3]. The mentioned determiners, as above noted, the direction of the lines of the continuous wave vector component in the zone ZB. Changing of the angle means turning these lines and approaching to (or moving away from) the Dirac points.

The results described above are in good agreement with the literature data about the pioresistance properties of carbon structures. For example, the dependences of the relative change of the resistance $\Delta R / R$ of carbon nanotubes thin-film samples on the relative strain of elongation $\delta$ were experimentally obtained in [14], and the monotonic nonlinear character of these dependences is shown.

Evaluation of the value of $\Delta R / R$ by means of the longitudinal component $M$ is calculated in this work for CNTs $(3,1)$ using the formula:

$$
\frac{\Delta R}{R}=\frac{-M \delta}{M \delta+1}
$$

at selected values of the relative microdeformation, $\delta=0.001$ showed the results $(\Delta R / R)_{\text {theor }} \approx 0.02$, close to the experimental data $(\Delta R / R)_{\exp } \approx 0.013$ and retaining the tendency of the monotonic nonlinear growth. The difference in the results, in our opinion, is due to the interaction between CNTs in the films and other types of deformations, which were not taken into account in the model calculations.

The review [15] presents the results of theoretical calculations of the calibration factor $K$ of a series of single-walled carbon nanotubes using the standard activation expression for the conductivity of semiconductors. Evaluation of the factor by the formula:

$$
K=\frac{-M}{M \delta+1}
$$

yields a value of $K=-18.96$ for $\delta=0.01$ and $K=-12.31$ for $\delta=0.035$ for CNTs $(15,4)$, which is in good agreement with this work, where it is also noted that the calibration factor of such nanotube increases slowly with the growth of elative deformation value.

\section{Conclusion}

Main results and conclusions on the basis of the carried out theoretical research are formulated in Conclusion.

1. The model of the electronic structure of chiral carbon nanotubes deformed by stretching and compression, within the framework of the tight-binding method is constructed.

2. It is shown that under the influence of compression and stretching deformations the band structure of semiconductor chiral CNTs changes with the subsequent variation of the band gap and the state density, which is indirectly influence on the change of the conductivity of the studied carbon nanoparticles and leads to the appearance of Mott transitions "conductor-semiconductor" and "semiconductorconductor".

3. The piezoresistance properties of chiral CNTs of different diameters and conductivity types are investigated. The longitudinal components of the elastoconductance tensor of chiral CNTs are calculated, and its dependence on the relative strain value and type is studied.

4. The obtained results can also be adapted for electromechanical nanosensor designs, based on the piezoresistance effect, and chiral CNTs are the main structural element. 


\section{REFERENCES}

1. Bir G.L., Pikus G.E. Simmetriya i deformatsionnye effekty v poluprovodnikakh [Symmetry and Deformation Effects in Semiconductors]. Moscow, Nauka Publ., 1972. 584 p.

2. Chernozatonskiy L.A., Sorokin P.B., Artyukh A.A. Novye nanostruktury na osnove grafena: fizikokhimicheskie svoystva i prilozheniya [New Nanostructures Based on Graphene: Physical and Chemical Properties and Applications]. Uspekhi khimii [Russian Chemical Reviews], 2014, vol. 83, no. 3, pp. 251-279.

3. Dyachkov P.N. Uglerodnye nanotrubki: stroenie, svoystva, primeneniya [Carbon Nanotubes: Structure, Properties, Applications]. Moscow, BINOM; Laboratoriya znaniy Publ., 2006. 293 p.

4. Eletskiy A.V. Mekhanicheskie svoystva uglerodnykh nanostruktur i materialov na ikh osnove [Mechanical Properties of Carbon Nanostructures and Materials Based on Them]. Uspekhi fiziki [Physic], 2007, vol. 177, no. 3 , pp. 233-274.

5. Izyumov Yu.A., Chashchin N.I., Alekseev D.S Teoriya silno korrelirovannykh sistem. Metod proizvodyashchego funktsionala [The Theory of Strongly Correlated Systems. The Method of Generating Functional]. Moscow, Regulyarnaya i khaoticheskaya dinamika Publ., 2006. 384 p.

6. Khan Z.H., Kermany A.R., Цchsner A., Iacopi F. Mechanical and electromechanical properties of graphene and their potential application in MEMS. Journal of Physics D: Applied Physics, 2017, vol. 50, pp. 053003 (1-24).

7. Kvasnikov I.A. Termodinamika i statisticheskaya fizika. T. 4: Kvantovaya statistika [Thermodynamics and Statistical Physics. Vol. 4: Quantum Statistics]. Moscow, KomKniga Publ., 2005. 352 p.

8. Lebedeva O.S., Lebedev N.G. Deformatsionnoe izmenenie zapreshchennoy shcheli primesnykh uglerodnykh nanotrubok [Deformational Change of the Band Gap of Impurity Carbon Nanotubes]. Khimicheskay a fizika [Russian Journal of Physical Chemistry], 2014, vol. 33, no. 10, pp. 73-80.

9. Lebedeva O.S., Lebedev N.G. Pyezorezistivnyy effekt v primesnykh odnosloynykh uglerodnykh nanotrubkakh v priblizhenii «Habbard-I» [Piezoresistance Effect in Impurity Single-Walled Carbon Nanotubes in the Hubbard-I Approximation]. Nauchno-tekhnicheskie vedomosti SPbGPU. Seriya «Fiziko-matematicheskie nauki» [St. Petersburg State Polytechnical University Journal. Physics and Mathematics], 2014, vol. 195, no. 2, pp. 149-161.

10. Lebedeva O.S., Lebedev N.G. Vliyanie deformatsiy rastyazheniya i szhatiya na pyezorezistivnost uglerodnykh nanotrubok i grafenovykh nanolent [Effect of Strain and Compression Deformations on the Piezoresistivity of Carbon Nanotubes and Graphene Nanofilms]. Nauchno-tekhnicheskie vedomosti SPbGPU. Seriya «Fiziko-matematicheskie nauki» [St. Petersburg State Polytechnical University Journal. Physics and Mathematics], 2014, vol. 189, no. 1, pp. 26-34.

11. Li Y., Wang W., Liano K., Hu C. Piezoresistive effect in carbon nanotube films. Chinese Science Bulletin, 2003, vol. 48, no. 2, pp. 125-127.

12. Lyapkosova O.S., Lebedev N.G. Pyezorezistivnyy effekt v odnosloynykh uglerodnykh nanotrubkakh [Piezoresistive Effect in Single-Walled Carbon Nanotubes]. Fizika tverdogo tela [Solid State Physics], 2012, vol. 54, no. 7, pp. 1412-1416.

13. Obitayo W. A, Liu T. Review: Carbon Nanotube - Based Piezoresistive Strain Sensors. Jornal of Sensors, 2012, vol. 2012, pp. 652438(1-15).

14. Pereira V.M., Castro Neto A.H., Peres N.M.R. Tight-binding approach to uniaxial strain in graphene. Physical Review B., vol. 80, no. 7, pp. 045401(1-8).

15. Saito R., Dresselhaus M.S., Dresselhaus G. Physical properties of carbon nanotubes. London, Imperial College Press, 1999. 251 p.

16. Tyablikov S.V. Metody kvantovoy teorii magnetizma [The Methods of the Quantum Theory of Magnetism]. Moscow, Nauka Publ., 1975. 528 p.

17. Vostrikov M.V. Sozdanie mikroelektromekhanicheskoy elementnoy bazy na baze tekhnologii MEMS [Creation of a Micro-Electromechanical Element Base Based on MEMS Technology]. Naukoemkie tekhnologii. MGTU imeni N.E. Baumana [High Technology. MSTU named after N.E. Bauman], 2007, pp. 223-228. 


\section{ПЬЕЗОПРОВОДИМОСТЬ ХИРАЛЬНЫХ УГЛЕРОДНЫХ НАНОТРУБОК В РАМКАХ МЕТОДА СИЛЬНОЙ СВЯЗИ}

\section{Ольга Сергеевна Лебедева}

Кандидат физико-математических наук, ассистент кафедры теоретической физики и волновых процессов, Волгоградский государственный университет lebedeva_os@volsu.ru, tf@volsu.ru просп. УНиверситетский, 100, 400062 г. Волгоград, Российская Федерация

\section{Николай Геннадьевич Лебедев}

Доктор физико-математических наук, профессор кафедры теоретической физики и волновых процессов, Волгоградский государственный университет nikolay.lebedev@volsu.ru, tf@volsu.ru просп. Университетский, 100, 400062 г. Волгоград, Российская Федерация

\section{Ирина Александровна Ляпкосова}

Кандидат сельскохозяйственных наук, доцент кафедры механики, Волгоградский государственный аграрный университет lyapkosova_irina@mail.ru просп. Университетский, 26, 400002 г. Волгоград, Российская Федерация

Аннотация. В работе представлены результаты теоретического исследования пьезорезистивных свойств хиральных углеродных нанотрубок с разным типом проводимости. С использованием метода сильной связи было получено аналитическое выражение электронного спектра хиральных деформированных углеродных нанотрубок. Внешние механические нагрузки провоцируют вариацию величины запрещенной зоны исследуемых наночастиц, что оказывает косвенное влияние на их проводимость. Это изменение проводимости под действием деформаций называется эффектом пьезосопротивления, который в свою очередь характеризуется пьезорезистивными константами. В рамках модели Хаббарда и метода функций Грина был проведен аналитический расчет такой константы - продольной компоненты тензора эластопроводимости. Исследована его зависимость от диаметра нанотрубок, величины относительной деформации продольного сжатия и растяжения. Дано физическое обоснование полученных результатов, проведено их сравнение с литературными данными.

Ключевые слова: тензор эластопроводимости, эффект пьезосопротивления, деформация сжатия и расширения, запрещенная зона. 